\title{
Soil carbon and nitrogen of Northern Great Plains grasslands as influenced by long-term grazing
}

\author{
A. B. FRANK, D. L. TANAKA, L. HOFMANN, AND R. F. FOLLETT
}

USDA Agricultural Research Service. Northem Great Plains Research Laboratory, P.O. Box 459, Mandan. N.D. 58554 and USDA Agricultural Research Senvice, Natural Resource Research Center, P.O. Box E, Ft. Collins, Colo. 80522

\begin{abstract}
Three mixed prairie sites at Mandan, N.D. were grazed heavily ( 0.9 ba steer $\left.{ }^{-1}\right)$, moderately $\left(2.6\right.$ ha steer $\left.^{-1}\right)$, or left ungrazed (exclosure) since 1916. These sites provided treatments to study the effects of long-term grazing on soil organic carbon and nitrogen content and to relate changes in soil carbon and nitrogen to grazing induced changes in species composition. Blue grama [Boutelozia gracilis (H.B.K.) Lag. ex Griffiths] accounted for the greatest change in species composition for both grazing treatments. Relative foliar cover of blue grama was $25 \%$ in 1916 and $85 \%$ in 1994 in the heavily grazed pasture and $15 \%$ in 1916 to $16 \%$ in 1994 in the moderately grazed pasture. Total soil nitrogen content was higher in the exclosure $\left(1.44 \mathrm{~kg} \mathrm{~N} \mathrm{ha}^{-1}\right)$ than in either grazing treatment $\left(0.92\right.$ and $1.07 \mathrm{~kg} \mathrm{~N} \mathrm{ha}^{-1}$ for moderately and keavily grazed, respectively) to $107-\mathrm{cm}$ depth. Soil organic carben content arg $7.2,6.4$, and $7.4 \mathrm{~kg} \mathrm{~m}^{-2}$ to $30.4 \mathrm{~cm}$ soil depth and $14.1,11.7$, and $14.0 \mathrm{~kg} \mathrm{~m}^{-2}$ to $106.7 \mathrm{~cm}$ soil depth for the exclosure, moderately grazed, and heavily grazed treatments, respectively. Compared to the exclosure the moderately grazed pasture contained $17 \%$ less soil carbon to the $106.7 \mathrm{~cm}$ depth. Eeavy grazing did not reduce soil carbon when compared to the exclosure. Based on ${ }^{13} \mathrm{C}$ analysis and soil organic carbon data to $15.2 \mathrm{~cm}$ depth, blue grama or other $C 4$ species contributed $24 \%$ or $1.2 \mathrm{~kg} \mathrm{~m}^{-2}$ of the total carbon in the heavily grazed and $20 \%$ or $0.8 \mathrm{~kg} \mathrm{~m}^{-2}$ of the total carbon in the moderately grazed pastures during the 1916 to 1991 time period. The increase in blue grama, a species with dense shallow root systems, in the heavily grazed pasture probably accounted for maintenance of soil carbon at levels equal to the exclosure. These results suggest that changes in species composition from a mixed prairie to predominantly blue grama compensated for soil carbon losses that may result from grazing native grasslands.
\end{abstract}

U. S. Deparment of Agriculture, Agriculnural Research Service, Northern Plains Aren, is an egual opportunity/ffifirmative action employer and all agency services are available without discrimination.

Trade and company names are included for the benefit of the reader and do nor imply any endorsement or preferential treatment of the product by the authors or USDA.

Manuscript accepted 15 Feb. 1995
Key Words: isotopic composition, C3 species, $\mathbf{C} 4$ species, rangeland, soil organic matter, Boutelou a gracilis

Soil organic matter dynamics are complex and affected by many factors such as temperature, precipitation, vegetation, soils, and management practices (Burke et al. 1989). When grasslands are tilled for crop production, and during years of subsequent tillage, mineralization of soil organic matter causes significant reductions in soil carbon (Tiessen et al. 1982, Aguilar et al. 1988, Blank and Fosberg 1989). Davidson and Ackerman (1993) reviewed numerous studies on effects of initial cultivation of previously untilled soils and concluded that the mean soil carbon loss from the A horizon was about $40 \%$ in 5 years.

Livestock grazing grasslands generally do not disturb the soil to the same extent as tillage, but grazing has been reported to decrease soil organic carbon. Bauer et al. (1987) reported reduced soil organic carbon, but not nitrogen content, of grazed native grasslands compared to ungrazed grasslands. Species composition of the grazed and the ungrazed grassland was not documented in that study. Fescue grasslands grazed at a heavy intensity of 0.2 ha animal unit month ${ }^{-1}$ (AUM) had less soil organic carbon than grasslands grazed at $0.8 \mathrm{ha} \mathrm{AUM}{ }^{-1}$ (Johnston et al. 1971). However, Smoliak et al. (1972) reported that the abundance of blue grama increased when sheep grazed native Stipa-Bouteloua prairie for 19 years at 2.5 ha AUM $^{-1}$ compared to 1.7 ha AUM $^{-1}$ which, in conjunction with increased manure deposition, increased soil carbon content.

The source of soil carbon has been studied using the stable isotope ${ }^{13} \mathrm{C}$ at natural abundances as a tracer of plant species contributions to soil carbon (Balesdent et al. 1987). Differences in enzymatic reactions between $\mathrm{C} 3$ and $\mathrm{C} 4$ plants during carbon fixation result in differences in isotopic composition of the plant tissue, from an average near $-27 \%$ and $-12 \%$ for $\mathrm{C} 3$ and $\mathrm{C} 4$ plants, respectively (Smith and Epstein 1971, Deleens et al. 1974). Balesdent et al. $(1988,1990)$ described the usefulness of using the natural abundance of ${ }^{13} \mathrm{C}$ for evaluating soil organic carbon turnover, tillage effects, and plant source of soil carbon.

The objectives of our study were to determine the effects of long-term grazing of Northern Great Plains mixed prairie on soil organic carbon and nitrogen content, and to relate changes in soil carbon to grazing induced changes in species composition. 


\section{Materials and Methods}

The study was conducted on adjacent moderately ( $46 \mathrm{ha}$ ) and heavily ( $16 \mathrm{ha}$ ) grazed mixed prairie pastures near Mandan, N.D. $\left(46^{\circ} 46^{\prime} \mathrm{N}\right.$, and $\left.100^{\circ} 50^{\prime} \mathrm{W}\right)$. The soil was a Temvik Silt Loam (fine-silty, mixed Typic Haplorborolls). The stocking rates were initially established in 1916 at 2.6 ha steer ${ }^{-1}$ for the moderately grazed and 0.9 ha steer ${ }^{-1}$ for the heavily grazed pasture. The grazing season extended from about mid-May to October each year. These stocking rates and grazing period have been maintained on the same pastures since 1916. An exclosure (0.02 ha) was also established within the moderately grazed pastures in 1916 and has been maintained ungrazed by livestock since.

The soil sampling procedures followed that of Bauer and Black (1981). Soil samples were collected from the 2 pastures and exclosure in the autumn of 1991. Four soil cores were taken near the top of the slope (typically 3-6\%) at 6 sites having the same soil, slope, and exposure (southeast) in each pasture and the exclosure. Each site was designated as a replicate for statistical analysis. The 4 cores were $15 \mathrm{~cm}$ apart and the sites $7 \mathrm{~m}$ apart. The undecomposed plant residue and residue in advanced stages of decomposition on the soil surface were removed and saved prior to cutting the soil core into depth increments. Soil cores $(6.7$ $\mathrm{cm}$ diam) were taken from 7 soil depth increments: 0-7.6, $7.6-15.2,15.2-22.8,22.8-30.4,30.4-45.6,45.6-76.2$, and $76.2-106.7 \mathrm{~cm}$. The soil from the 4 cores was composited for each depth increment and placed in plastic bags in the field. Samples trere immediately processed after collection by removing all visible root segments. A subsample was taken from the composited cores to determine total soil water content by weight and to calculate bulk density. Soil bulk density was calculated from oven dry $\left(105^{\circ} \mathrm{C}\right.$ for $\left.72 \mathrm{hour}\right)$ soil mass and cylinder volume for each depth increment. The remainder of the sample was weighed, dried $\left(31^{\circ} \mathrm{C}\right.$ for 72 hour), crushed to pass through a 2 $\mathrm{mm}$ sieve, ground to $200 \mu \mathrm{m}$, and stored in glass bottles for total organic carbon and nitrogen analysis.

Total organic carbon and nitrogen contents were determined using a Carlo Erba model NA1500 automatic carbon-nitrogen analyzer (Haake Buckler Instruments, Inc., Saddle Brook, N.J.) as described by Schepers et al. (1989). The procedure involves the combustion of samples, based on the Dumas principle. The processed soil samples were weighed into tin containers and treated with $3 \mathrm{ml}$ of $0.1 \mathrm{M} \mathrm{HCl}$ to remove carbonates. The samples were redried at $60^{\circ} \mathrm{C}$ before determination of carbon and nitrogen contents.

The carbon isotope signatures were determined on air dried subsamples of the soil from all treatments. The $\delta^{13} \mathrm{C}$ of the $\mathrm{C} 4$ regetation, which was used in calculating the percent of soil organic carbon derived from $\mathrm{C} 4$ vegetation, was determined on oven dried $\left(65^{\circ} \mathrm{C}\right)$ finely ground samples of blue grama [Boutelouta gracilis (H.B.K.) Lag. ex Griffiths] vegetation (leaves and stems) clipped from the heavily grazed pasture. Automated combustion isotope ratio mass spectrometer analysis was accomplished using a Tracermass stable isotope analyzer (Europa Scientific Ltd.. Crew, England) coupled to a Carlo Erba C/N anaIyzer (Haake Buckler Instruments, Inc., Saddle Brook, N.J.) (Marshall and Whitehead 1985). Soil samples analyzed for ${ }^{13} \mathrm{C}$ were from the 0-7.6 and 7.6-15.2 cm depths. Carbonates were removed from the soil by shaking $5 \mathrm{~g}$ soil in $100 \mathrm{ml} 0.1 \mathrm{~N}$ $\mathrm{NH}_{3} \mathrm{PO}_{4}$. The ${ }^{13} \mathrm{C}$ composition is expressed relative to the $\mathrm{PDB}$ standard as a $\delta^{13} \mathrm{C}$ value in units per mil $(\% o$ ). The proportion of soil organic carbon accumulated in the grazed pastures since 1916 relative to the exclosure that was derived from plants with C4 metabolism, mainly blue grama in our study, was calculated from the equation:

Percent C4 origin carbon $=\frac{\delta^{n} \mathrm{C} \text { Soil grazed pasture }-\delta^{n} \mathrm{C} \text { Soil exclosure }}{\delta^{n} \mathrm{C} \text { Vegention blue grama }-\delta^{n} \mathrm{C} \text { Soil exclosure }} \times 100$

The $\delta^{13} \mathrm{C}$ of blue grama vegetation (leaves and stems) from the heavily grazed pasture was $-13.28 \%$, which was assumed to be representative of $\mathrm{C} 4$ vegetation in this study. We assume for these calculations that since species changes in the exclosure were small, the $\delta^{13} \mathrm{C}$ of soil organic carbon in 1991 would be similar to that at the beginning of the grazing trials. The percent of total soil organic carbon originating from $\mathrm{C} 4$ species prior to starting grazing in 1916 was calculated using $-27 \% o$ as the $\delta^{13} \mathrm{C}$ of the exclosure soil.

Vegetative composition of each pasture and exclosure was taken from annual reports of research conducted on the pastures since 1916. Vegetative composition data were not available for all years of the study. Measurements for 1916, 1947, and 1949 were made from about late-June to mid-July from 10 quadrants $\left(\mathrm{m}^{2}\right)$ per pasture. In 1994 measurements were made in October. Percent live relative foliar cover, or the proportion of foliar cover attributed to a single species, was recorded for both pastures in 1916 and 1947, and the exclosure in 1949 by making visual estimates. Vegetative composition data for 1964, 1984, and 1994 were obtained by the point frame technique and used to calculate relative foliar cover.

The soil carbon and nitrogen concentrations were statistically analyzed using SAS repeated measures analysis by depth. Error variances for depths were heterogeneous, so only univariate analysis are reported for depth. Carbon and nitrogen accumulation to depths of $30.4 \mathrm{~cm}$, which coincides with the depth increment of greatest root density in blue grama, and $106.7 \mathrm{~cm}$, the greatest depth sampled, were analyzed using SAS GLM procedures (SAS 1990). Mean separation for all analysis was conducted using the Waller-Duncan test $(P<0.05$, unless otherwise stated). These long-term grazed pastures were not replicated. For statistical purposes each of the 6 sites per treatment was designated as replicates, as also reported by Bauer and Black (1981) and Bauer et al. (1987). The absence of pasture replication is of concern, but the data obtained from 76 years of grazing history on the same pastures is worthwhile information.

\section{Results and Discussion}

Changes in vegetation composition were greater in the heavily grazed pasture compared to the moderately grazed pasture and the long-term exclosure (Table 1). The moderately grazed pasture retained a mix of species similar to the exclosure, but the heavily grazed pasture became dominated by blue grama, a C4 metabolism species. Blue grama composition was $15 \%$ for the moderately grazed and $20 \%$ for the heavily grazed pastures prior to starting grazing in 1916 (exclosure data not available for 1916), and the exclosure composition was $12 \%$ in 1949 and $0 \%$ in 1994. In 1994, Kentucky bluegrass (Poa pratensis L.) made up a significant proportion of the foliar cover for the exclosure and moderately grazed treatments. Blue grama changed more than any other species in both pastures during the period from 1916 to 1994 . In 
Table 1. Relative foliar cover of species in the exclosure and the moderately and heavily grazed mixed prairie pastures.

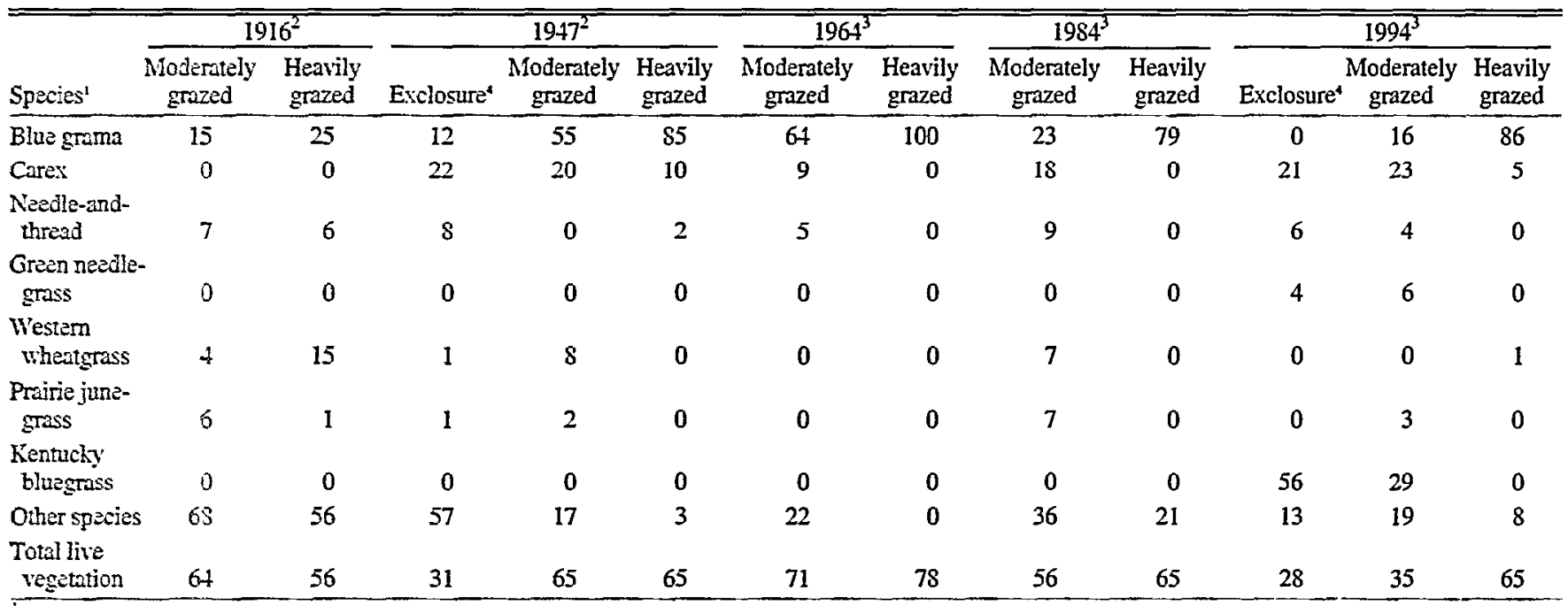

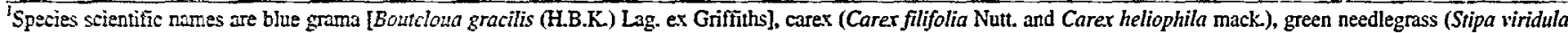
Trin.), neeóle-and-thread (Stipa comata Trin. and Rupr.), western wheatgrass [Pascopyntm smithii (Rybd) Löve], prairie junegrass [Koeleria pyramidata (Lam) Beauv.], and Trin.), needle-and-thread (Stipa comata
Kentudky bluegrass (Psa pratensis L).

Relature foliar cover from visual estimates.

"Relatuve foliar cover from point frame measurements.

Telatus foliar cover for $19+9$.

the moderately grazed pasture blue grama varied from a low of $15 \%$ in 1916 to a high of $64 \%$ in 1964 and in the heavily grazed pasture from $25 \%$ in 1916 to $100 \%$ in 1964 . These data show that blue grama composition varied with time and that a major change in species composition did accur among the treatments which resulted in a higher proportion of blue grama vegetation in the heavily grazed pastures.

Soil organic carbon concentration by depth was not statistically different between the exclosure and the heavily grazed pasture, but the exclosure had significantly higher soil carbon concentration than the moderately grazed pasture at the 0-7.6, 7.6-15.2, 15.2-22.8, and 45.6-76.2 cm depths (Table 2). Soil carbon concentration was different between the heavily and moderately grazed pastures only at the 7.6-15.2 and $45.6-76.2 \mathrm{~cm}$ depth. Soil organic carbon decreased at each successive depth increment. The trand for differences between treatments for soil organic carbon content on an area basis (data not shown) was similar to the concentration data.

Soil organic carbon content from 0-30.4 and 0-106.7 cm soil depths were the same in the exclosure and the heavily grazed pasture, and both were greater than in the moderately grazed pasture (Table 3). The heavily grazed pasture contained about $16 \%$ more

Table 2. Soil orgaric carbon concentration at 7 depths in the exclosure, heavily grazed, and moderately grazed treatments.

\begin{tabular}{lccc}
\hline \hline Depth & Exclosure & Moderately grazed & Heavily grazed \\
\hline $\mathrm{cm}$ & $\ldots-1.1 \mathrm{a}^{1}$ & $32.6 \mathrm{~b}$ & $34.6 \mathrm{~b}$ \\
$0-$ & 7.6 & $36.5 \mathrm{~b}$ & $25.5 \mathrm{a}$ \\
$7.6-15.2$ & $23.7 \mathrm{a}$ & $21.2 \mathrm{~b}$ & $16.7 \mathrm{ab}$ \\
$15.2-22.8$ & $19.8 \mathrm{a}$ & $15.4 \mathrm{~b}$ & 12.8 \\
$22.8-30.4$ & 14.1 & 11.4 & 10.4 \\
$30.4-45.6$ & 11.6 & 10.2 & $7.0 \mathrm{a}$ \\
$45.6-76.2$ & $7.8 \mathrm{a}$ & $5.6 \mathrm{~b}$ & 3.8 \\
$76.2-106.7$ & 3.9 & 3.2 & \\
\hline
\end{tabular}

WWithin sous means followed by same letter are not different at $P \leq 0.05$ by WallerDuncan test carbon than the moderately grazed to the $30.4 \mathrm{~cm}$ depth. Carbon in the surface $30.4 \mathrm{~cm}$ of soil accounted for slightly over half or 51,53 , and $55 \%$ of total carbon to $106.7 \mathrm{~cm}$, for the exclosure, heavily grazed, and moderately grazed, respectively. To the 107.6 $\mathrm{cm}$ depth, the exclosure and the heavily grazed pastures contained $17 \%$ more soil organic carbon than the moderately grazed pasture. These results suggest that moderate grazing slightly reduced soil organic carbon content. Reductions were similar to that reported by Bauer et al. (1987) who found that ungrazed grassland contained consistently greater soil organic carbon than grazed grasslands. These differences may be attributable, in part, to carbon removal by grazing animals. Johnston et al. (1971) suggested that the reduction in soil organic matter in pastures heavily grazed by cattle was due to increased soil erosion. However, in the heavily grazed pastures in this study there has been no visual indication of any soil erosion.

Nitrogen concentration among treatments was significantly different only at the 45.6-76.2 and 76.2-106.7 $\mathrm{cm}$ depth (Table 4), although $\mathrm{N}$ concentration trended higher at all depths in the exclosure compared to the grazed pastures. The higher $\mathrm{N}$ content of the surface $0-30.4$ and $0-106.7 \mathrm{~cm}$ of soil in the exclosure suggests that grazing reduced soil $\mathrm{N}$ (Table 3 ).

Lorenz and Rogler (1967) studied rooting depth in these same

Table 3. Soil organic carbon and nitrogen content for the $0-30.4$ and 0-106.7 depth increments in the exclosure, heavily grazed, and moderately grazed treatments.

\begin{tabular}{lccc}
\hline \hline Depth & Exclosure & Moderately grazed & Heavily grazed \\
\hline $\mathrm{cm}$ & $-1 . \mathrm{a}^{1}$ & $6.4 \mathrm{~b}$ & $7.4 \mathrm{a}$ \\
$0-30.4$ & $14.1 \mathrm{a}$ & $11.7 \mathrm{~b}$ & $14.0 \mathrm{a}$ \\
$0-106.7$ & & $-1.7 \mathrm{~K} \mathrm{~m}^{-2}$ & \\
$\mathrm{~cm}$ & $0.76 \mathrm{a}$ & $0.57 \mathrm{~b}$ & $0.58 \mathrm{~b}$ \\
$0-30.4$ & $1.44 \mathrm{a}$ & $0.92 \mathrm{~b}$ & $1.07 \mathrm{~b}$ \\
$0-106.7$ & &
\end{tabular}

Within row means followed by the same letter are not different at $P \leq 0.05$ by WallerDuncan test. 
Table 4. Soil nitrogen concentration at 7 depths in the exclosure, heavily grazed, and moderafely grazed treatments.

\begin{tabular}{|c|c|c|c|}
\hline Depth & Exclosure & Moderately grazed & Heavily grazed \\
\hline $\mathrm{cm}$ & $\cdots+\cdots$ & $\ldots-\mathrm{g} \mathrm{N} \mathrm{kg}^{-1} \ldots$ & $-+-6-2-0-1$ \\
\hline $0=7.6$ & 3.25 & $2.6 \mathrm{~S}$ & 2.67 \\
\hline $7.6-15.2$ & 3.13 & 1.56 & 1.95 \\
\hline $15.2-22.8$ & 2.08 & 1.67 & 1.35 \\
\hline $228-304$ & 1.39 & 0.97 & 1.04 \\
\hline $30.4-45.6$ & 0.93 & 0.66 & 0.84 \\
\hline $45.6-76.2$ & $0.67 \mathrm{a}$ & $0.38 \mathrm{c}$ & $0.53 b$ \\
\hline $76.2-106.7$ & $0.57 \mathrm{a}$ & $0.22 b$ & $0.24 \mathrm{~b}$ \\
\hline
\end{tabular}

Within rows means followed by same letter are not different at $P \leq 0.05$ by WallerDunean test.

hearily and moderately grazed pastures in 1961 and found that root weight was similar to $122 \mathrm{~cm}$ depth. There was, however, a larger percent of root weight present in the surface $30 \mathrm{~cm}$ of the heavily grazed compared to the moderately grazed pastures, which they attributed to the greater composition of blue grama. Coupland and Johnson (1965) reported that blue grama rooting depth was $19 \mathrm{~cm}$ less than needle-and-thread (Stipa comata Trin. and Rupr.) and $29 \mathrm{~cm}$ less than western wheatgrass [Pascopyrum snithii (Rybd.) Love]. Both needle-and-thread and western wheargrass are common cool-season species in the AgropyronStipa dominated Northern Great Plains mixed prairie. These results suggest that the increase in blue grama may have been the reason soil organic carbon content in the heavily grazed pasture was maintained near levels present in the ungrazed exclosure. Some reduction in soil organic carbon can be caused by grazing alone, since grazing reduces root biomass (Johnston et al. 1971). In our snidy the differences between the exclosure and the moderately grazed pasture may reflect grazing effects, whereas differences batween the exclosure and the heavily grazed pasture may reflect species effects on soil organic carbon content.

The amount of partially decomposed plant residue present on the soil surface suggests that large amounts of carbon are stored at this level in these systems. The amount of decomposed plant residue present on the soil surface when soil samples were collected was $4.1,2.9$, and $2.9 \mathrm{~kg} \mathrm{~m}^{-2}$ for the exclosure, moderately, and heavily grazed treatments (exclosure is significantly greater, $P<0.07$ ), respectively. The carbon concentration of the residue was 10.0 .8 .5 , and $7.4 \%$, (exclosure is significantly greater than the heary) which equates to $0.44,0.25$, and $0.21 \mathrm{~kg}$ carbon $\mathrm{m}^{-2}$ in the decomposed residue on the soil surface in the exclosure, moderate, and heavy treatments, respectively. The $\mathrm{C} / \mathrm{N}$ ratio of the partially decomposed residue was significantly greater for the henvily grazed pasture (17.3) compared to the exclosure (14.2) and the moderately grazed pasture (14.8). The higher $\mathrm{C} / \mathrm{N}$ ratio for the heavily grazed compared to the moderately grazed and exclosure treatments suggests either a slower rate of decomposition or a greater portion of recent plant material in the residue.

Differences in soil $\mathrm{N}$ content between the grazing treatments were small, but coincided well with soil organic carbon content, which should be the case in a relatively stable grassland system. The $\mathrm{C} / \mathrm{N}$ ratio was not different among treatments and averaged 11.3, 13.3, and 13.S for the exclosure, heavily grazed, and moderafely grazed treatment, respectively. Our results are similar to those of Smoliak et al. (1972) who reported that heavy grazing induced species changes resulting in shallower rooting species, which along with increased manure deposition from the grazing animals in their study increased soil organic carbon but not $\mathrm{N}$ content. However, our data differ from that of Bauer et al. (1987) who reported that grazed grasslands contained less carbon and more $\mathrm{N}$ than adjacent ungrazed grasslands. They suggested that $\mathrm{N}$ Ioss from the system by soil denitrification, and ammonia volatilization from plant residues accounted for the lower $\mathrm{N}$ content in the ungrazed grasslands. The effect of vegetation changes in the heavily grazed pasture from mainly cool-season grasses to blue grama, a warm-season grass, on the source of the soil organic carbon was determined from the $\delta^{13} \mathrm{C}$. The average $\delta^{13} \mathrm{C}$ of tissue of $\mathrm{C} 3$ and $\mathrm{C} 4$ plants is about $-27 \%$ and $-12 \%$, respectively (Smith and Epstein 1971, Deleens et al. 1974). The $\delta^{13} \mathrm{C}$ was lower at both the 0-7.6 and 7.6-15.2 cm depths for the exclosure than for both grazing treatments (Table 5) confirming the greater

Table 5. Average $\delta^{13} \mathrm{C}$ of soil organic matter at 2 depths for the exclosure, heavily grazed, and moderately grazed treatments.

\begin{tabular}{|c|c|c|c|}
\hline Depth & Exclosure & Moderately grazed & Heavily grazed \\
\hline $\mathrm{cm}$ & $\ldots \ldots \ldots$ & $\delta^{10} \mathrm{C}(\%(0)-\cdots$ & $\ldots+2-1$ \\
\hline $0-7.6$ & $-23.05 c^{1}$ & $-21.43 b$ & $-20.74 a$ \\
\hline $7.6-15.2$ & $-21.20 b$ & $-19.19 a$ & $-19.24 a$ \\
\hline
\end{tabular}

${ }^{1}$ Within rows means followed by same letter are not different at $P \leq 0.05$ by WallerDunean test.

vegetation composition of $\mathrm{C} 3$ species in the exclosure. At the $0-7.6 \mathrm{~cm}$ depth the soil organic carbon of the moderately grazed pasture had a lower $\delta^{13} \mathrm{C}$ than the heavily grazed pasture. At the 7.6-15.2 depth there were no statistical differences in $\delta^{13} \mathrm{C}$ between the moderately and heavily grazed pastures.

The greater $\delta^{12} \mathrm{C}$ in the heavily and moderately grazed pastures than in the exclosure coincides with the grazing-induced increase in blue grama vegetation. The differences in $\delta^{13} \mathrm{C}$ between the exclosure and the heavily grazed pasture were greater at the 0-7.6 $\mathrm{cm}(2.31 \% \mathrm{co})$ than at the $7.6-15.2 \mathrm{~cm}$ depth $(1.96 \%$ o), which coincides with the reported greater root density of the shallower rooting blue grama. Based on the avg $\delta^{13} \mathrm{C}$ at both depths and soil organic carbon data, blue grama or other $\mathrm{C} 4$ species was the source of $24 \%$ or $1.2 \mathrm{~kg} \mathrm{~m}^{-2}$ of the soil organic carbon formed in the heavily grazed and $21 \%$ or $0.8 \mathrm{~kg} \mathrm{~m}^{-2}$ of carbon formed in the moderately grazed pastures to $15.2 \mathrm{~cm}$ depth during 76 years of grazing. The percentage of the total soil organic carbon present in these pasture soils that formed from $\mathrm{C} 4$ plant species during preand post-1916 grazing was $49 \%$ for the moderately and $51 \%$ for the heavily grazed.

These data suggest that perhaps bluc grama is a more cfficient producer of soil organic carbon than the other species present in a mixed prairie of the Northern Great Plains as represented by the moderately grazed pasture. The data indicate that heavy grazing did not reduce soil organic carbon compared to the exclosure, but that moderate grazing did slightly reduce soil organic carbon. These results suggest that the higher composition of blue grama vegetation in the heavily grazed pasture probably partitions more carbon to the soil than the typical mixed prairie moderately grazed pasture. The source of the additional soil carbon in the blue grama dominated pastures may be attributable to greater root density and turnover, or possibly to higher rates of root exudate 
from blue grama than from other species present in a mixed prairie of the Northem Great Plains.

\section{Literature Cited}

Aguilar, R., E. F. Kelly, and R. D. Heil. 1988. Effects of cultivation on soils in Norhern Great Plains rangeland. Soil Sci. Soc. Amer. J. 52:1081-1085.

Balesdent, Jerome, Andre Mariotti, and Bernard Guillet. 1987. Natural ${ }^{13} \mathrm{C}$ abundance as a tracer for studies of soil organic matter dynamics. Soil Biol. Biochem. 19:25-30.

Balesdent, J., A. Mariotti, and D. Boisgontier. 1990. Effect of tillage on soil organic carbon mineralization estimated from ${ }^{13} \mathrm{C}$ abundance in maize fields. J. Soil Sei. 41:587-596.

Balesdent, J., G. H. Wagner, and A. Mariotti. 1988. Soil organic matter tunover in Jong-term field experiments as revealed by carbon-13 naiural abundance. Soil Sci. Soc. Amer. J. 52:118-124.

Bauer, Armand, and A. L. Black. 1981. Soil carbon, nitrogen, and bulk density comparisons in two cropland tillage systems after 25 years and in virgin grassland. Soil Sci. Soc. Amer. J. 45:1166-1170.

Barer, Armand, C. V. Cole, and A. L. Black. 1987. Soil property comparisons in virgin grasslands between grazed and nongrazed management systems. Soil Sci. Soc. Amer. J. 51:176-182.

Blark, R. R., and M. A. Fosberg. 1989. Cultivated and adjacent virgin soils in northecntral South Dakota: I. Chemical and physical comparisons. Soil Sci. Soc. Amer. J. 53:1484-1490.

Eurke, I. C., C. M. Yonker, W. J. Parton, C. V. Cole, K. Flach, and D. S. Schimel. 1989. Texture, climate, and cultivation effects on soil organic matter content in U.S. grassland soils. Soil Sci. Soc. Amer. J. 53:800-\$05.
Coupland, R. T., and R. E. Johnson. 1965. Rooting characteristic of native grassland species in Saskatchewan. J. Ecol. 53:475-507.

Davidson, Eric A., and Ilse L. Ackerman. 1993. Changes in soil carbon inventories following cultivation of previously untilled soils. Biogeochem. 20:161-193.

Deleens, E., J. C. Lerman, A. Nato, and A. Moyse. 1974. Carbon isotope discrimination by the carboxylating reactions in C3, C4 and CAM Plants. In: Proceedings of the Third International Congress on Photosynthesis, Rehovot, Israel (M. Avron, Ed.), pp. 1267-1276. Elsevier, Amsterdam.

Johnston, A., J. F. Dormaar, and S. Smoliak. 1971. Long-term grazing effects on fescue grassland soils. J. Range Manage. 24:185-188.

Lorenz, R. J., and G. A. Rogler. 1967. Grazing and fertilization affect root development of range grasses. J. Range Manage. 20:129-132.

Marshall, R. B., and J. N. Whitehead. 1985. Automation of an interface between a nitrogen analyzer and an isotope ratio mass spectrometer. Analyst (London) 110:867-871.

SAS Institute, Inc. 1990. SAS/STAT User's Guide, Version 6, Fourth Edition, Vol. 2, SAS Inst., Cary, N. C. 886 pp.

Schepers, J. S., D. D. Francis, and M. T. Thompson. 1989. Simultaneous determination of total $\mathrm{C}$, total $\mathrm{N}$, and ${ }^{15} \mathrm{~N}$ on soil and plant material. Commun. Soil Sci. Plant Anal. 20:949-959.

Smith, B. N., and S. Epstein. 1971. Two categories of ${ }^{13} \mathrm{C} /{ }^{12} \mathrm{C}$ ratios for higher plants. Plant Physiol. 47:380-384.

Smoliak, S., J. F. Dormaar, and A. Johnston. 1972. Long-term grazing effects on Stipa-bouteloua prairie soils. J. Range Manage. 25:246-250.

Tiessen, H., J. W. B. Stewart, and J. R. Bettany. 1982. Cultivation effects on the amounts and concentration of carbon, nitrogen, and phosphorus in grassland soils. Agron. J. 74:831-835.

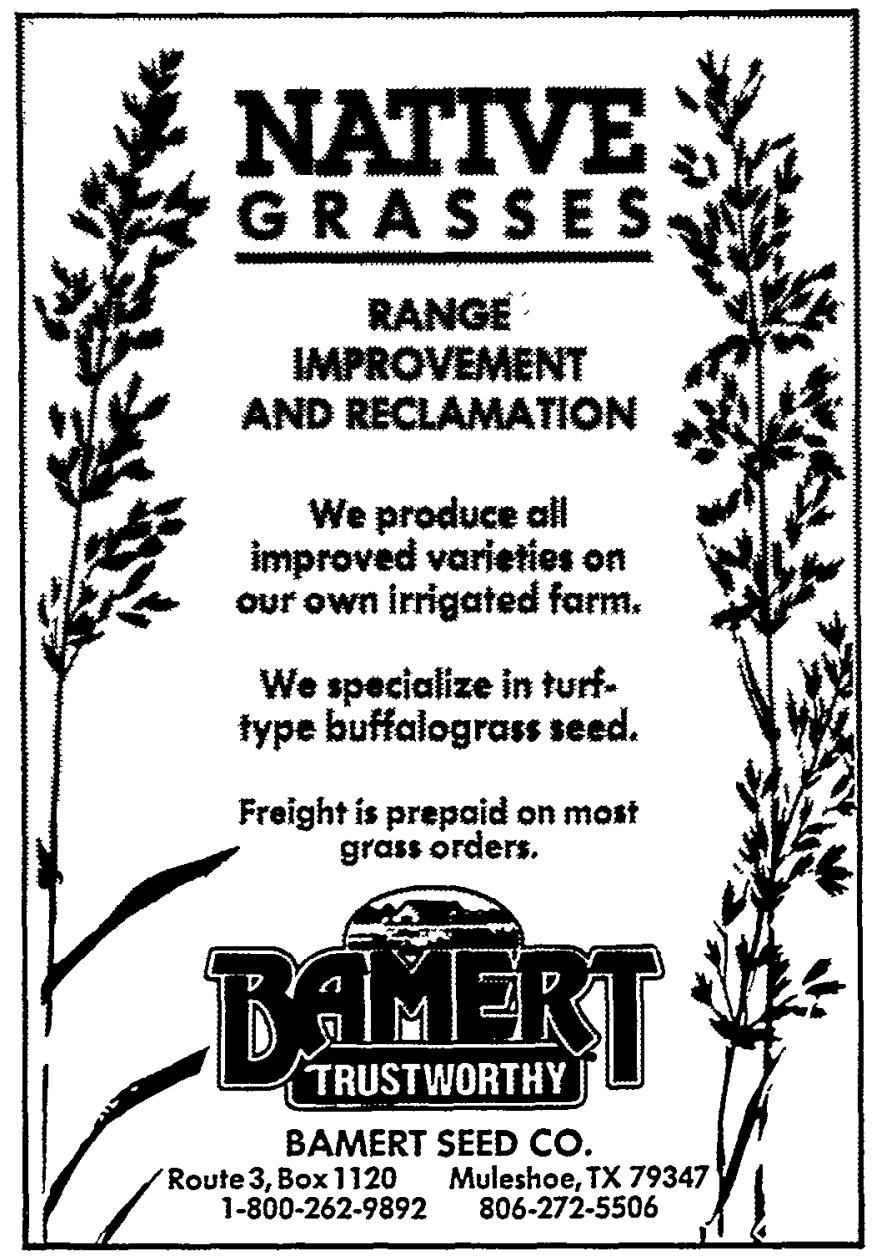

